\title{
Workplace quality and labour turnover in the electronics industry of the Pearl River Delta, China
}

\author{
Contrasting employer and employee perspectives
}

\begin{abstract}
Export-oriented manufacturing firms in developing countries need to be highly flexible in order to respond to demand changes in volatile global markets. By using a modified version of Atkinson's flexible firm concept as a framework, it is the aim of this paper (i) to describe the impact of workplace quality on labour turnover and (ii) to derive implications of this relationship for upgrading processes. Empirical data are combined from two surveys of migrant workers and electronics firms in the Pearl River Delta, China.
\end{abstract}

Keywords: flexible firm, upgrading, workplace quality, labour turnover, China

\section{Introduction}

Since the implementation of China's opening policy (1978), the Pearl River Delta in the southern region of the country has developed into the so-called 'factory of the world' for flexible and wage-sensitive production in labour-intensive sectors of light industry (ENRIGHT et al. 2005). One of the most important sectors involved in this rise is the electronics industry, which is responsible for approximately $39 \%$ of the value added of the region (GDSTATS 2010) and is particularly tightly integrated into globally organised value chains (Meyer et al. 2009; Meyer et al. 2012; SturGEON 2002). The Pearl River Delta, with its large growth dynamic for industrial value added and its flexible production model, is subject to strong cyclical deviations, both seasonal and related to its dependence on exports. During the most recent global economic and financial crisis, the growth rate of the gross domestic product (GDP) in Guangdong fell from $10.5 \%$ in 2008 to $5.8 \%$ in the first quarter of 2009 (Yu/Zhang 2009) - and in Dongguan even more so, from $14.0 \%$ to $-3.5 \%$ (YU/ HuANG 2009).

Moreover, the shortage of workers, which was already a problem before the crisis (He 2006; YANG 2005), has now been making headlines once again since 2010 following a short interruption during the crisis years (The Economist
29.7. 2010, KNIGHT et al. 2011). The financial crisis was only temporarily able to mask the demographic effects of the one child policy, which are becoming apparent in that the 18-24 years age group, which is so important for industrial companies, is shrinking. An additional problem is the fact that the economic development of the inland regions of China is providing increasingly attractive job opportunities for migrant workers in their home provinces, and the demands of the younger generation of workers are beginning to increase. The current generation is less willing than previous ones to accept the low quality of jobs, i.e. the often monotonous, physically straining and dangerous working conditions, in relation to the financial rewards, further benefits and qualification requirements (YUE et al. 2010). Companies are thus complaining of high rates of labour turnover, with a personnel substitution rate of $30-40 \%$ per year being a fairly midrange figure (HÜRTGEN et al. 2009, 226); for companies with foreign investment, the turnover rate is estimated to be between $30 \%$ and $90 \%$ (Pun/Smith 2007, 36 ff.), since job changing, i.e. employees moving to another company, is triggered initially by minimal differences in wage costs, and is also generally possible without any significant difficulties due to homogeneous and weak regulation, low qualification requirements and low demands of the positions on workers. 
Against this background, CHAN (2010a) speaks of a Chinese paradox consisting of a shortage of migrant workers in the coastal provinces and a surplus of labour supply in the rural regions. In his opinion, the Lewisian turning point (LEWIS 1954), at which the unlimited supply of labour from rural areas dries up and wages steadily begin to increase, has not yet been reached. The Hukou system and an increased demand for workers in rural areas stemming from the 2009 economic stimulus package have had a particularly distorting effect on price formation on the job market. The former worsens the negotiation position of rural workers in the coastal regions, while the latter has led to a temporary rise in the number of non-agricultural job possibilities in rural regions. CHAN (2010b) does not expect the situation of workers or the stability of working conditions to change unless the access to a local Hukou at the job location is simplified. The first signs of this are evident in the province of Guangdong, which is most heavily affected by the current shortage of workers, in that it is aiming to provide 1.8 million qualified migrant workers with a local Hukou within the next three years (CHAN 2010a).

In the following hypothesis it will be examined that the labour market in the region is caught in an inefficient 'lock-in' situation, i.e. trapped in a situation in which the incentive structures do not lead to investment in qualification on the part of companies and workers. Workers are not primarily interested in long-term qualifications, but rather in short-term income maximisation. Companies make virtually no investment in qualification measures and improved working conditions, since these are not honoured by increased loyalty on the part of workers, and, due to the short-term orientation of the business model, are not necessary either. In the long term, however, this hampers - and sometimes even blocks - the upgrading process towards better quality production and qualification as well as more stable employment conditions.

Two questions are at the centre of this investigation:

- To what extent do the quality of jobs and employee characteristics influence job changes undertaken by employees and the labour turnover in companies?
- Does a qualification lock-in exist in the electronics industry of the Pearl River Delta in the area of labour-intensive and wage-sensitive production, and if so, how can this be overcome?

Firstly, basic theoretical principles concerning the connection between flexibility and company success will be discussed, and determinants for job change will be demarcated. Quantitative survey data from companies and workers will be combined methodically. On this basis, workplace quality and its variation as well as the influence of workplace quality on the employee turnover rate of the companies will be determined, followed by a summary of the results and a derivation of policy recommendations.

\section{Flexible company organisation and labour turnover}

The term flexibility established itself in this context in the 1980 s and was taken up by international organisations (e.g. OECD, IMF) and governments from the 1990s onwards. This promoted a normative research dialogue regarding the necessity of flexibilisation of company organisation and the erosion of normal working conditions in the course of a farreaching flexibilisation of companies. As a counterpoint to this, REILLY (1998) called for a more detailed differentiation of flexibility requirements and the empirical investigation of flexibility potential at the individual, company and regulation levels.

\section{The flexible firm in the Chinese context}

Flexibilisation in the Western context aims to increase adaptability within an existing political-economic system. However, this development must be categorised very differently in the Chinese context with its gradual socio-economic transformation to a market economy. There, the newly formed private economic sector has been geared towards a high degree of flexibility from the beginning. It is clearly evident that the organisation of manufacturing companies in the Pearl River Delta is characterised by a tight integration into global production processes. The volatility of demand connected to this requires a high degree of flexibility in terms of production volumes. But how do these market requirements translate to the level of company organisation? 
Fig. 1: The flexible firm in the context of Chinese low-cost production

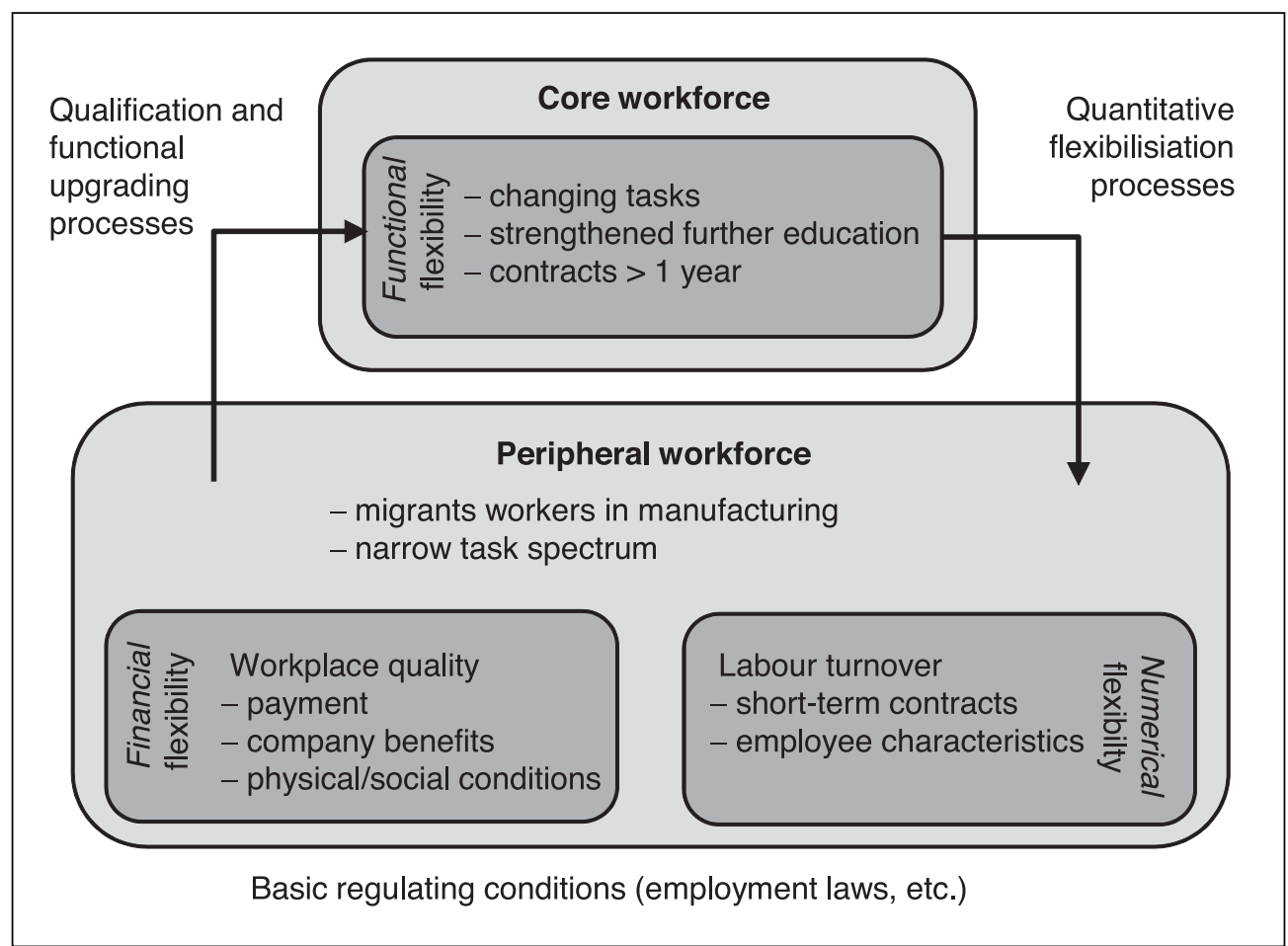

Source: own draft, based on ATKINSON 1984, 29

Albrecht $(2002,2005)$ has produced studies on flexibilisation in German-speaking geography which refer in their typology of flexibility to earlier works from the field of company research. AtKinson (1984) developed the first typology of flexibility forms within companies. According to him, various workforce groups contribute in different ways to increasing the flexibility of a company through their own flexible deployment: the core workforce of long-term employees should be flexible in the carrying out of their function. The peripheral workforce, which makes up the largest number of employees, is affected by numerical and financial flexibility (Fig. 1). Numerical flexibility refers to a varying number of employees depending on the needs of the company; financial flexibility concerns the wage policy of the company being linked to fluctuations in demand, and in the Western context, also measures such as commission on profits. Under certain circumstances though, the advantage of an efficiently controllable person- nel volume, which may be achieved through flexible company organisation, can actually become a disadvantage. Numerical flexibility, for instance, involves considerable costs for recruitment and training. Even though WhITELEY et al. (2000) estimate these costs to be lower than those for a regularisation of the workforce, a high fluctuation can prove to be a liability for companies in China, especially in a situation of job surplus and labour shortage (JIANG et al. 2009).

ATKINSONs flexibility typology has, until now, only been further differentiated for the Western investigation context (e.g. REILLY 1998; VALVERDE et al. 2000), which is of little use for the Chinese context. For example, subcategories of the peripheral workforce, which are widespread in the context of the USA and Europe, and particularly in The Netherlands and Great Britain (part-time and formalised temporary work, job sharing, as well as publicly subsidised professional training within companies), are still 
generally absent from the manufacturing companies in China. There, a third, purposely unregulated segment of the labour market is developing in the course of the transformation process between a rural and urban economy: a market segment of migrant workers (míngōng) (HEBEL/SCHUCHER 2006). This initiative designed to mobilise labour resources is well known as a success factor for China's economic boom, but at the expense of social security, since the migrant workers, of which there are more than 200 million, must retain their primary residence in their home towns under this so-called Hukou system. This means that access to the social security system at their work locations has so far remained blocked for them (health insurance, pension schemes, unemployment insurance and the subsidised accommodation market, along with school education). This results in much lower personnel costs for companies for these migrant workers than those for the locally registered workers, but in wages which are still much more attractive for the migrant workers than those in their home regions, thus creating the basis for the competitive advantage of Chinese production companies over other production locations. Activities in low-cost production requiring little or no qualification, which form the focal point of employee-based investigations, are almost exclusively carried out by migrant workers. Such employment arrangements are often short-term (up to one year, linshi zhigong) and rarely mid to long-term (changqi zhigong) (STAIGER 2008). These considerations lead to a modified conception of the flexible firm (Fig. 1).

Due to the high degree of quantitative flexibilisation in the production companies, it is to be expected that the workforce is strongly segregated, also in terms of qualifications. Qualification-based segregation is defined in this case as the concentration of employees with a certain qualification level within a company, although differing qualification standards certainly exist between companies (GERLACH et al. 2002). Through outsourcing of production activities, qualification-based segregation is generally on the increase (TSERTSVADZE 2005). Because of the specialisation of Chinese companies in simpler production activities, segregation within the global value chain means that in China, a very small proportion of highly qualified core workers is juxtaposed in the manufacturing industry with a large proportion of poorly qualified migrant workers in the peripheral workforces for simple production activities. In contrast, the globally active customer firms in industrial countries are characterised by an increasing proportion of highly qualified employees.

The effects of qualification-based segregation in internal company learning processes have not yet been empirically verified. From a conceptional perspective, however, it can be assumed that a functional and qualification-based specialisation that is too one-sided will have negative effects on learning and will make the transition of employees from the peripheral to the core workforce more difficult. Such mobility, however, would be a starting point for technological and organisational upgrading processes, since the building up of basic technological capabilities is often a result of continual incremental improvements and knowledge stemming from experience (KIM 1997), with the increase of absorptive capacity through qualified human resources also playing a decisive role (COHEN/LEVINTHAL 1990). The empirical investigation of this research project thus concentrates particularly on the examination of the peripheral (production and migrant workers) and their potential role for upgrading processes.

In accordance with the segregation theory, an observation of the Chinese electronics industry clearly shows that the sector is characterised by a high degree of heterogeneity. On the one hand, there is the small number of technologically very active companies which receive almost unlimited support from the state and have established international innovation activities, while on the other hand, there is the vast majority of companies which possess virtually no technological competences or absorptive capacity (ERNST/NAUGHTON 2008). The two sectors of the branch coexist almost entirely separate from one another, meaning that knowledge spillover and the development of a coherent innovation system cannot realistically be expected (KROLL/SCHILLER 2011).

\section{Flexibility, workplace quality and labour turnover}

Against the background of the transformation processes in China and their overriding influence on increased labour turnover, possible determinants for a change of jobs at the company level will be discussed, both from an employee 
(supply) and employer (demand) perspective.

Employer perspective: In accordance with the flexibility maxim, a company aims for an efficiently directed personnel volume suited to the current demand situation. The varying need for labour must thus be seen as the most important determinant from the company point of view for labour turnover. In this specific context, it is managed through contracts and simplified through a weakly regulated environment (SHEN 2007; LÜTHJE 2008; HÜRTGEN et al. 2009). The conditions determining workplace quality are geared to a large extent towards financial flexibility, and are thus only marginally focused on the provision of consistent social welfare measures. Cost advantages are the principal determining factor behind decisions and generally entail an achievement-based wage policy in companies.

Of particular importance in terms of upgrading processes from the company perspective are also the human resources available and the qualification of workers present within the company. Qualification measures consist here of education programmes upon entry into the company or both internal and external further education programmes provided by the firm. Qualification of workers in the production area is potentially beneficial for a transition to the core workforce and for the reduction of labour turnover through greater job security, more diverse spectra of activity and improved income possibilities. For the empirical investigation, on the other hand, it can be suspected that the probability of a job change increases if the expected educational benefits following a qualification initiative do not materialise for an individual employee. Particularly for large labour markets - such as the Pearl River Delta - the expectation is that the incentive for companies to invest in further education diminishes, since changes in personnel increase following further education due to the larger number of alternative employment options for workers, and because the relevant qualification requirements can be obtained by companies through the labour market (BRANDT 2009). However, an empirical investigation is still required in order to determine whether this hypothesis derived from the Western context can be applied to the Chinese situation.

Employee perspective: Employees (Fig. 1, peripheral workforce), a heterogeneous research group, may be categorised according to characteristics such as age, gender, education and occupation. When considering labour turnover, one must take into account how important various company benefits are to the different groups of employees and what benefits they indeed encounter in companies. The conditions provided in companies can be categorised according to physical, social and organisational factors, as well as the company benefits mentioned above.

In the context of Chinese companies, three aspects are of particular importance for the understanding of workplace quality and labour turnover. Firstly, there has been a change in the attitude among migrant workers, which still constitute the largest proportion of poorly qualified employees. In this case, however, it is not so much the Lewisian 'turning point' which is able to explain the shortage of labour and rising wages (CHAN 2010a), but rather the increased demands of the second generation of migrant workers in terms of their working conditions and environment, since alternative vocational possibilities are now emerging in the peripheral regions and there is a current tendency towards a reduction in the importance of family support in favour of other migration motives and strategies (FAN 2008; YUE et al. 2010). Secondly, wages are the central argument for the selection or change of jobs, although it is not only the amount which plays a significant role, but also the reliability of wage payments, since non-payment of wages is the most common cause of industrial conflict (SHEN 2007). Thirdly, social welfare benefits must be categorised differently in China to the way in which this is done in Europe. Accommodation, food and recreational activities are often all provided by the company, although this is primarily done for the purpose of exercising better control over employees on the company site (PUN 2005). Against the background of the changing attitude of migrant workers, this old model of total provision of amenities is starting to become less attractive.

\section{Data and methods}

The data used for the present investigation encompass the perspectives of both the companies and the employees and were gathered using two standardised questionnaires. These were carried out in cooperation with the De- 
partment of Urban and Regional Planning of Sun Yat-sen University in Guangzhou and were completed at the beginning of 2008. The coupling of the two sets of survey results is a particularly fruitful endeavour, especially as it allows for the capturing of both workplace quality and job change from the perspective of employees, as well as the company view of the workforce and the effects of job changes on the companies themselves. Several different parameters were investigated in the course of the surveys, among both companies and workers (e.g. wage levels, other benefits, qualification), in order to achieve a validation of the data through a comparison of results.

\section{Company data}

The data for the company perspective were taken from a standardised survey of 222 electronics firms in the Pearl River Delta. The survey was conducted in cities with a large proportion of companies from the electronics industry. The data set encompasses 90 companies in Dongguan and 116 in Guangzhou. The companies in Dongguan were selected using the Guangdong Electronics Company Catalogue 2007; in Guangzhou, a list of companies from the Municipal Bureau of Statistics was used. 300 questionnaires (150 per city) were distributed to randomly selected companies following an introductory telephone conversation in advance. The response rate was $59 \%$ for Dongguan and $77 \%$ for Guangzhou. Telephone follow-up efforts were successful in raising the quality of survey answers and in reducing the number of unanswered questions to a minimum. Due to a lack of structural company information (e.g. size or owner) in the lists used to select the samples, a test of representativeness was not possible. The high response rate, however, reduces the danger of a systematically distorted non-answering of questions.

The section of the company survey pertaining to employees, which is relevant for this study, contained only closed questions in order to make it easier to provide answers by telephone or post. The companies were particularly asked to make statements about the workers identified as belonging to the peripheral workforce, which, in the Pearl River Delta, mostly consists of migrant workers. Furthermore, a distinction was often made in the data set during the analysis between the 114 private Chinese firms and the 102 foreign companies (including Hong Kong and Taiwan), since a further aim was to determine whether the two groups also differ in terms of workplace quality and flexibility as they do in terms of technological competences (SCHILLER 2011).

\section{Employee data}

The primary data used for the employee perspective were taken from a social geography field study which consisted of both a standardised survey of 585 workers (of which 566 cases were suitable for analysis) and a qualitative collection of data. The latter included 35 interviews with migrant workers, representatives of authorities, organisations and employment agencies as well as participating and non-participating observations in the factories and the working environment of low-cost manufacturing. Considering this large amount of data, this study will concentrate on the survey data.

The decisive criteria for the selection of the investigation area and the sample were that it should be a manufacturing location with a large proportion of low-cost production in the electronics industry where the above-mentioned data could be gathered. This selection process was faced with the following limitations: 1 . a target group, which can only be captured exploratively (migrant workers); 2 . politically related restrictions for domestic and foreign scholars, as well as for the investigation group in China.

Migrant workers are highly mobile, meaning that only a small proportion of them are covered statistically by local authorities, with the majority only being registered with the companies which employ them. The choice was made not to seek access to the subjects via companies, for example those participating in the above-mentioned company survey, since no guarantee could be made that company management would not influence the statements of respondents. However, the alternative methods of gathering data, i.e. in the public sphere, required legitimisation from public authorities. The Chinese partner institute of the study maintains research contacts with Tangxiazhen in Dongguan, which legitimised the gathering of the data. With the knowledge that other locations in the Delta are also specialised in the electronics industry (e.g. Shilong, Chang'an), Tangxiazhen was deemed suitable for the data collection, since the industry there is dominated by low-cost manufacturing for the export economy with a large proportion of electronics 
companies. The industrial, demographic and accompanying socio-economic transformation processes there are typical for the eastern axis of the Pearl River Delta (KILIAN et al. 2010).

The sample selection took place in two steps: First, two areas dominated by the electronics industry were selected (cluster sampling). The inner-city industry district 138 (304 valid questionnaires) has been well established since the middle of the 1990s. The peri-urban district Keyuancheng (262 valid questionnaires) has been occupied by companies since 2005 and is still undergoing development. In the second step, migrant workers were handed a questionnaire on the way from the company site to the shopping street which they filled out on the spot and returned immediately. Of those who accepted the questionnaire, the response rate was $100 \%$, although some of the questionnaires were not filled out completely. The scope of the sample is thus individually labelled.

\section{Workplace quality and labour turnover}

\section{Company perspective}

In accordance with the distinction mentioned above, workplace quality from the company perspective is measured using the factors income, social welfare benefits, the design of employment contracts, training and further education programmes, and qualification of workers. The flexibilisation of working conditions is then investigated using the turnover rate, the variation in the number of workers throughout the year, the length of time required to increase the number of employees by $10 \%$, as well as typical problems with the workforce. A differentiation is made between Chinese and foreign companies, as well as between Chinese companies at different locations and of different sizes for selected indicators.

Workplace Quality: The average monthly wages of the companies surveyed, at approximately 1,300 Yuan, were found to be well above the legal minimum wage of 780 Yuan in Guangzhou and 680 Yuan in Dongguan at the time of the survey (2007). This suggests that the labour shortage discussed in the introduction, which has created particularly strong competition for qualified workers and for pay- ment benefits not affecting the basic minimum wage, for example for overtime, night shift bonuses, gratuities, had already driven wages upwards prior to that time. As of May 2010, the minimum wage was adjusted once again to 1,030 Yuan in Guangzhou and 920 Yuan in Dongguan (HKTDC 2010). In the survey data, no significant differences can be found between Chinese and foreign companies, which contradicts the frequently proposed assumption that foreign companies have an advantage when competing for labour resources due to higher wages.

Questions about five benefits provided by companies over and above the standard wages revealed that almost $90 \%$ of companies offer accommodation in a company residential home, and nearly as many also provide meals as well as health and accident insurance. Paid holiday and gifts on festive occasions, especially at New Year, are much less widespread, but nevertheless standard at least for half of the companies surveyed. The social welfare benefits provided by foreign companies tend to be slightly greater than those of Chinese companies, although the differences are only significant for health and accident insurance. When combining wages and social welfare benefits, therefore, only a marginal advantage for foreign companies could be found. At this point it must be taken into consideration that the social welfare benefits investigated here must be interpreted differently within the Chinese context from the way in which they are seen in Europe. In this regard, PUN (2005) points to the controlling function of company residential homes. A high degree of social benefits of this kind thus characterises those companies which still follow the classical production model, which is increasingly coming to be considered unattractive by the younger generation of migrant workers.

Two-thirds of employment contracts were individually negotiated and concluded in written form. The practice of verbal contracts, which is illegal under the new Chinese employment contracts law of 2008 (GEFFKEN et al. 2010) is now very rare, even among Chinese companies, although it is still significantly more important in these firms than in foreign companies. Due to the minimal importance of verbal contracts, no investigation has been made as to their effects on the rate of labour turnover. 
Tab.1: Selected indicators of workplace quality from the company perspective

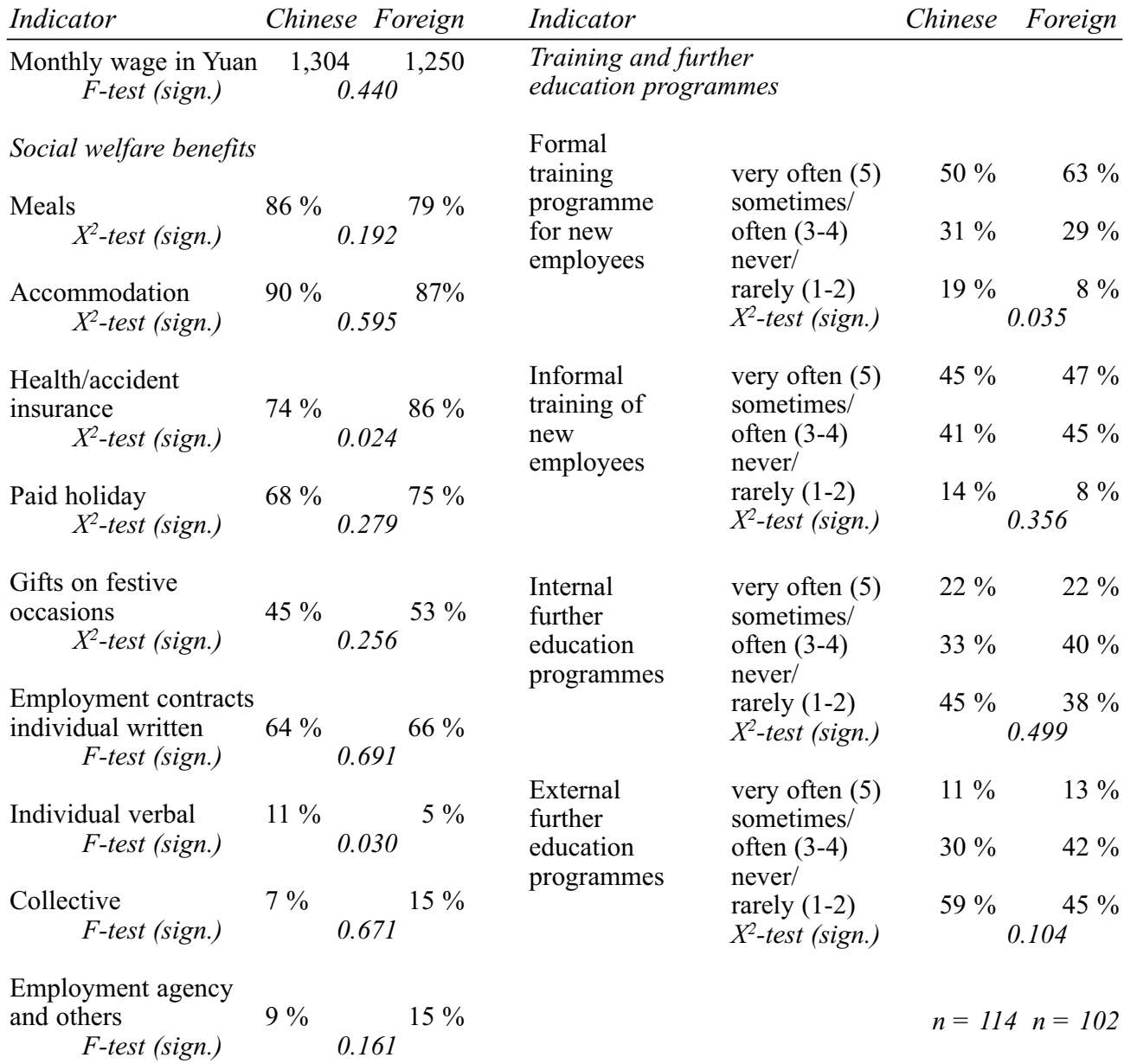

Source: own calculation, company survey 2008

Concerning training and further education, the following results emerged: much fewer than half of the companies offer training and further education measures very frequently. Training and learning phases occur most often when new workers commence employment with the company, while further education is only regularly offered internally in every fifth company and externally by every tenth company. Foreign companies offer significantly more possibilities in this area of formal training, as well as in cooperation with external providers of further education. In the areas of informal training and internal further education, the differences are not significant.
With regard to educational qualifications as an indicator for the qualification of employees, it could be determined that the group of poorly qualified workers with no more than a completed intermediate school education is in the majority. Approximately another quarter have a completed secondary school education, with roughly the same number having a vocational school qualification, while fewer than $10 \%$ have a university degree. A surprising finding was that Chinese companies have more highly qualified employees on average. The differences are particularly significant in the area of vocational school qualifications. This may possibly be explained by the fact that foreign com- 
Tab. 2: Selected indicators of job flexibility from the company perspective

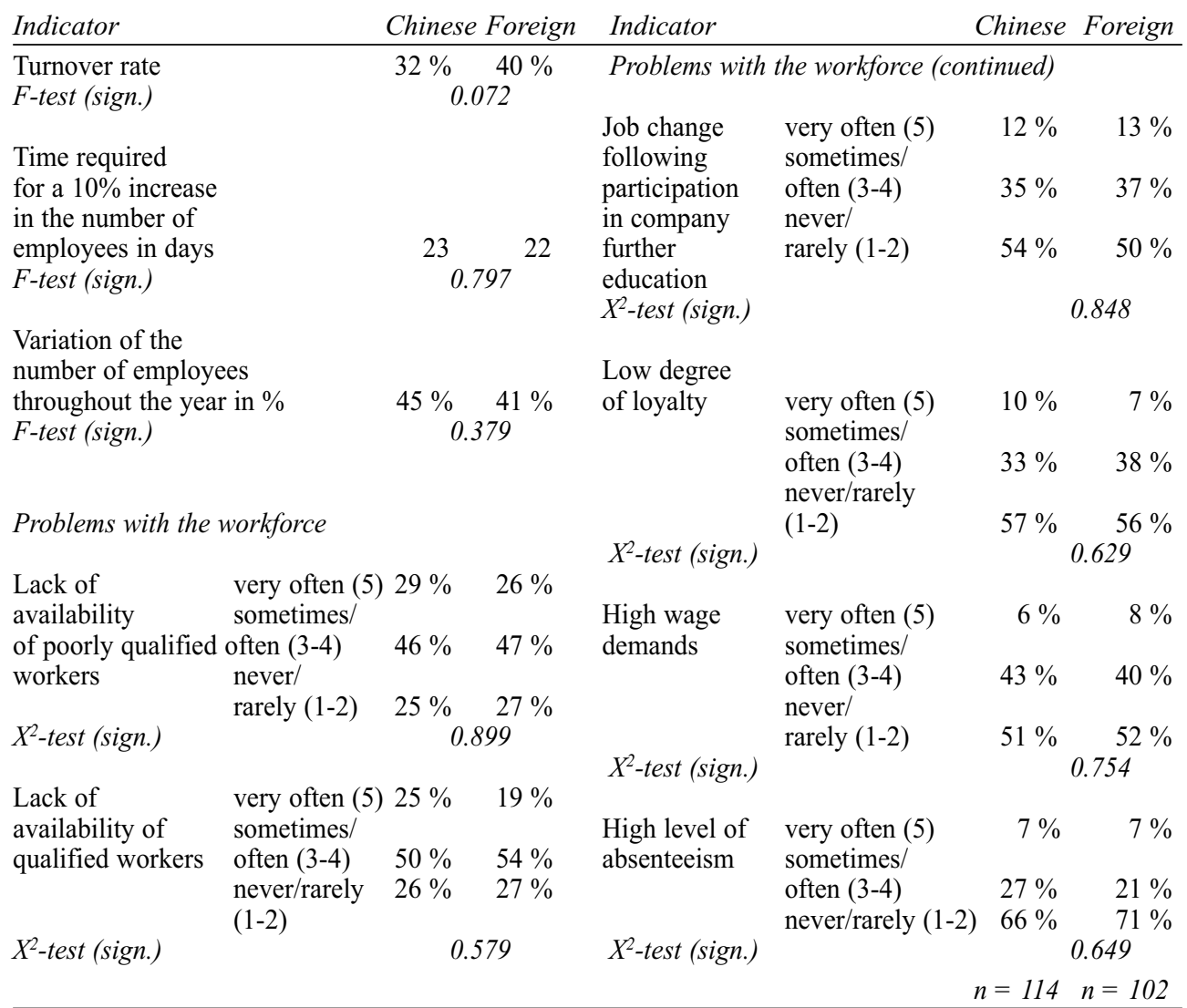

Source: own calculation, company survey 2008

panies rarely locate their more valuable functions in China, rather tending to do so in their native countries or in Hong Kong.

Labour turnover as an indicator for numerical flexibility: The empirical data produced an average fluctuation rate of $36 \%$ which roughly concurs with the values found in the relevant literature for China. Compared with reference values from Germany, this figure is very high. The German Federal Employment Agency (2010) quotes a figure of $15 \%$ in 2009 for the manufacturing industry in Germany. This confirms that the labour market in the Pearl River Delta is indeed characterised by a high rate of turnover. Whether this is a result of the shortage of workers on the supply side and a high labour turnover rate due to differences in wages, or whether it is to do with the demand side because of a high degree of uncertainty regarding job security, cannot be answered at this stage, but will be addressed again later using the results of the regression analysis.

The fluctuation rate in foreign companies is significantly higher than in Chinese companies (Tab. 2). This is also in line with the results of previous studies (PUN/SMITH 2007) and underlines the reliability of the survey data. This discrepancy is primarily a result of the extremely high rate of fluctuation in Taiwanese companies $(52 \%)$ which display a significantly different result from other foreign companies. This constitutes a preliminary indication that foreign companies, and particularly Taiwanese companies, are obviously unable to compensate for the disadvantage in wage levels through additional social welfare benefits or qualification 
measures: Chinese workers apparently react primarily to monetary incentives, while traditional forms of social welfare benefits, especially company residential homes, are no longer perceived as being attractive.

The level of employee numbers also varies considerably and, seen over the course of the entire year, is situated within a corridor of variation which is, on average, $43 \%$ of the average number of employees wide. A large proportion of production in the electronics industry is seasonal business, since a significant share of sales turnover in the industrial countries occurs during the Christmas period. There is no significant difference between Chinese and foreign firms in this regard. Larger companies with more than 500 employees can absorb these fluctuations better; their volatility, at $34 \%$, is significantly smaller than for companies with fewer than 100 employees, which arrive at a value of $54 \%$. The electronics companies in the Pearl River Delta generally have the ability to adapt very quickly to fluctuations in demand. For a $10 \%$ increase in the number of employees, they require an average of only 23 days.

A further indicator for workplace quality and flexibility is provided by the frequency with which companies report having problems with the workforce (Tab. 2). The most common problem mentioned was the shortage of poorly qualified workers, which was more frequently spoken about than the problem of acquiring qualified workers. This confirms the shortage of all labour resources in the region. Chinese companies are slightly more frequently confronted with these two problems, but the difference is not significant. The third most frequent problem mentioned by companies was job change following participation in a further education programme. This underlines the considerable readiness to change one's job based on wage discrepancies, especially when newly acquired qualifications open up possibilities to receive higher wages. The question of whether there is truly a positive statistical connection between qualification measures and fluctuation which 'punishes' those companies which invest in further education will be addressed at a subsequent point in the investigation.

\section{Employee perspective}

As the presented results demonstrate, the labour turnover discussed from the company perspective does not affect all employees in the same manner. First, the sample of 566 migrant workers surveyed must be described: $52 \%$ originate from Henan, Hebei and Hunan, three inland provinces of China, where the minimum wage is approximately one-third lower than in Dongguan (CLB 2008). This considerable wage gap between the regions of origin and occupation illustrates the attractiveness of the Delta as a destination for vocational migrants. $57 \%$ of the migrant workers are female, and only $28 \%$ are married, which is not surprising considering the low average age (23.8 years). These figures all roughly correspond to those found in other studies on migrant workers in Shenzhen (e.g. WANG/Wu 2010). The qualification level of the workers surveyed is also similar to that found in the company survey; the majority $(53 \%)$ had completed an intermediate school education.

A comparison of the two data catchment areas reveals the following differences: Older, male and married workers are significantly more frequently found in the inner city district than in the newly developed peri-urban area, as are those employed as salaried workers. The workers in the peri-urban industrial area, who are 2.5 years younger on average, have more frequently held a larger number of jobs in the past, and their current employment relationship has existed for seven months fewer than that of those in the inner city industry district. The peri-urban industrial area thus tends to employ a younger and also more mobile worker generation than the inner city industry district 138 . This result may indeed extend the discussion on the new generation of workers in terms of their preferred working location (PUN/Lu 2010; YUE et al. 2010).

Flexibility and company benefits: In approximately two-thirds of cases $(66 \%)$, there is a fixed written contract between employees and companies, although contracts are often concluded for a period of only one year (Fig. 1, linshi zhigong). Long-term employees only received a contract with the passing of the revised version of the employment contracts law (2008), even though they had mostly already worked for several years in the same company. $47 \%$ of the sample participants were aware of the new employment contracts law. Their opinion of it varied in roughly equal numbers between scepticism regarding the implementation at the company level and enthusiasm due to the 
Tab. 3: Selected employee characteristics

\begin{tabular}{|c|c|c|c|c|c|}
\hline Variables & $\begin{array}{l}\text { Characteristic } \\
\text { features }\end{array}$ & Frequency & $\begin{array}{l}\text { Distributi } \\
\text { areas }(\%) \\
\text { Inner city }\end{array}$ & $\begin{array}{l}\text { n across industrial } \\
\text { Peri-urban }\end{array}$ & $\chi^{2}$ (sig.) \\
\hline \multirow{2}{*}{$\begin{array}{l}\text { Occupation* } \\
(\mathrm{n}=444)\end{array}$} & Industrial workers & 367 & 50 & 50 & \multirow[t]{2}{*}{0.110} \\
\hline & Salaried employees & 77 & 60 & 40 & \\
\hline \multirow{2}{*}{$\begin{array}{l}\text { Gender } \\
(\mathrm{n}=565)\end{array}$} & Male & 243 & 66 & 34 & \multirow{2}{*}{0.001} \\
\hline & Female & 322 & 44 & 56 & \\
\hline \multirow{2}{*}{$\begin{array}{l}\text { Family status } \\
(\mathrm{n}=564)\end{array}$} & Married & 160 & 63 & 37 & \multirow[t]{2}{*}{0.060} \\
\hline & Unmarried & 404 & 50 & 50 & \\
\hline \multirow{4}{*}{$\begin{array}{l}\text { Age } \\
(n=555)\end{array}$} & up to 18 & 81 & 42 & 58 & \multirow[t]{4}{*}{0.001} \\
\hline & 19 to 24 & 296 & 50 & 50 & \\
\hline & 25 to 29 & 81 & 54 & 46 & \\
\hline & 30 and older & 97 & 72 & 27 & \\
\hline \multirow{2}{*}{$\begin{array}{l}\text { Education } \\
(\mathrm{n}=561)\end{array}$} & Max. intermediate & 316 & 55 & 45 & \multirow[t]{2}{*}{0.550} \\
\hline & Above intermediate & 245 & 52 & 48 & \\
\hline
\end{tabular}

* analogous to blue-/white collar workers;

** analogous to the Chinese chu zhong, nine compulsory years of schooling

Source: own calculation, employee survey 2008

promise of the eagerly awaited regulation and strengthened social security. At any rate, the contracts seemed to provide no effective barrier concerning numerical flexibility at the time of the survey, i.e. the rapid entry to and exit from an employment relationship.

The wage level was found to be lower than in the company survey; in both survey areas and occupational groups, it was reported to be around 1,140 Yuan. For this payment, however, the inner city employees work fewer hours than those in the peri-urban district (on average 9.6 vs. 9.8 hours/day; with 4.7 vs. 4.0 free days/month). The conventional assumption, that a higher level of education and a higher age are honoured with higher wages was found to be applicable to this sample as well. Furthermore, long-term employees earned significantly more than those employed for a short period $(r=0.54)$. A very small, but also significant correlation $(\mathrm{r}=0.13)$ exists between the number of previous jobs and the entry wage level (margin of error of $0.01 \%$ in each case). The wages were reported to be paid punctually in $80 \%$ of cases.

The industrial conflicts and strikes covered in other studies (e.g. Pun/Lu 2010; SMITH 2006) are not reflected in these data. However, the wages do vary depending on the company's order situation. The level of monthly wages fluctuates between the minimum and maximum figure with an average difference of around 550 Yuan, i.e. approximately half of the average wage level. In only 18 of 566 cases is the wage level constant from the beginning. For $65 \%$ of workers, the average wage is above their starting wage level; $19 \%$ actually earned more at the beginning of their employment relationship than their current monthly average. An explanation for this could be, that in times of high sales demand, workers are attracted by offering higher effective wages, which are then reduced in times of low demand to the level of the minimum wage. In this manner, company flexibility externalises market-related uncertainties by transferring them to workers. The determinants and fluctuations of the effective monthly wage will be revisited in the course of the discussion on reasons for job change.

The spectrum of company benefits (Fig. 2) is mostly filled with accommodation and meal solutions, with transport and childcare being a rare occurrence. In more than $50 \%$ of cases, health 
Fig. 2: Company benefits

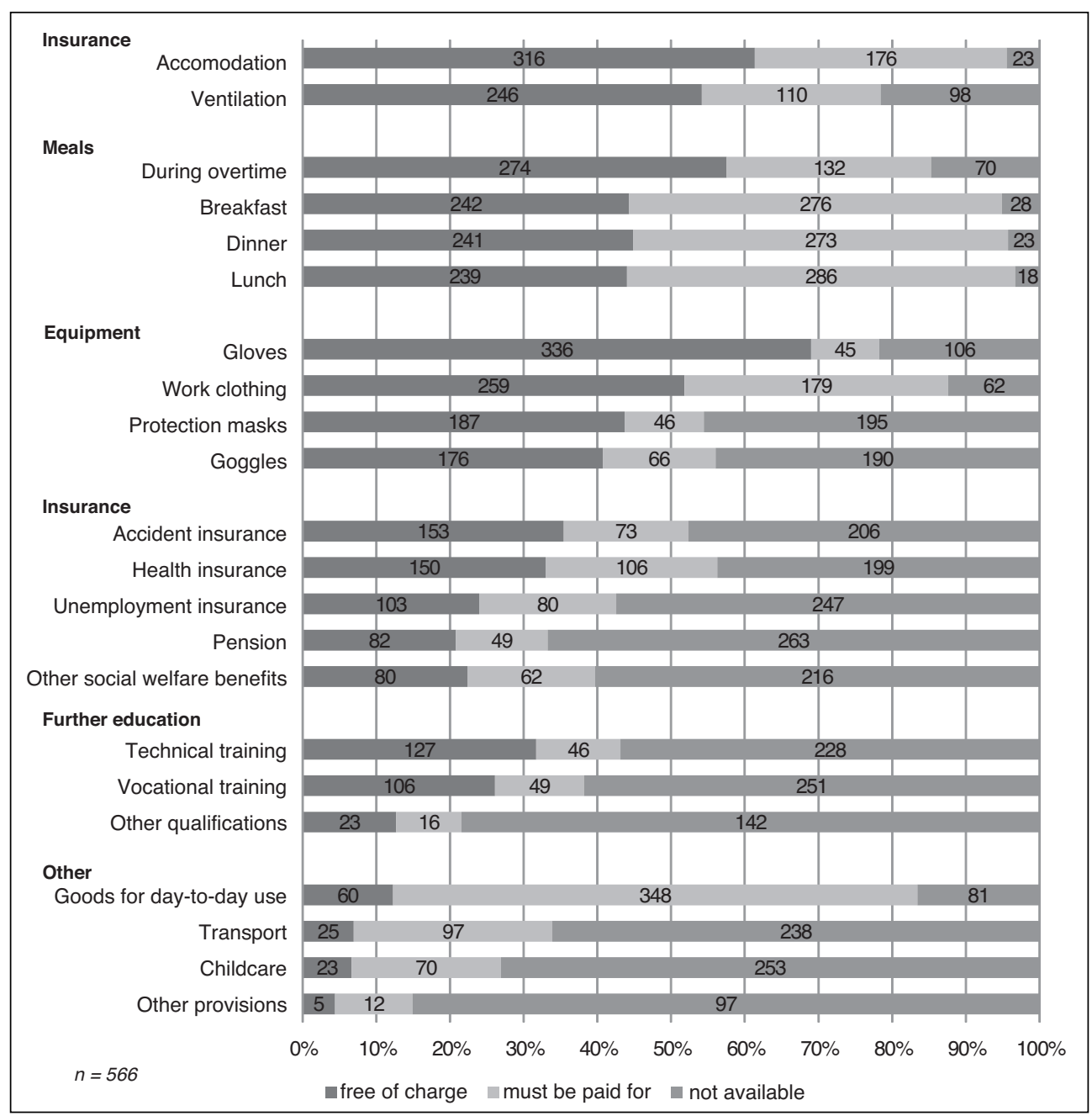

Source: own calculation, employee survey 2008

and accident insurance is offered, and $35 \%$ and $40 \%$ of cases involve offers of company-supported retirement schemes and unemployment insurance respectively - a figure which could conceivably have been much lower.

Further education measures are in place in around $40 \%$ of cases - a high figure considering the expectation that unqualified workers would generally receive no training. Moreover, training for industrial workers is similarly common to that for salaried employees. This includes all categories imaginable, from initial training to further education programmes, which must be more subtly differentiated for a more in-depth interpretation.

$79 \%$ of those surveyed were living in residential homes provided by the company, with a similarly high proportion receiving meals from the company canteen. As was the case with wages though, both figures lie beneath those resulting from the company survey, but both reveal the same tendency. A dominant charac- 
Fig. 3: Evaluation of workplace quality by employees

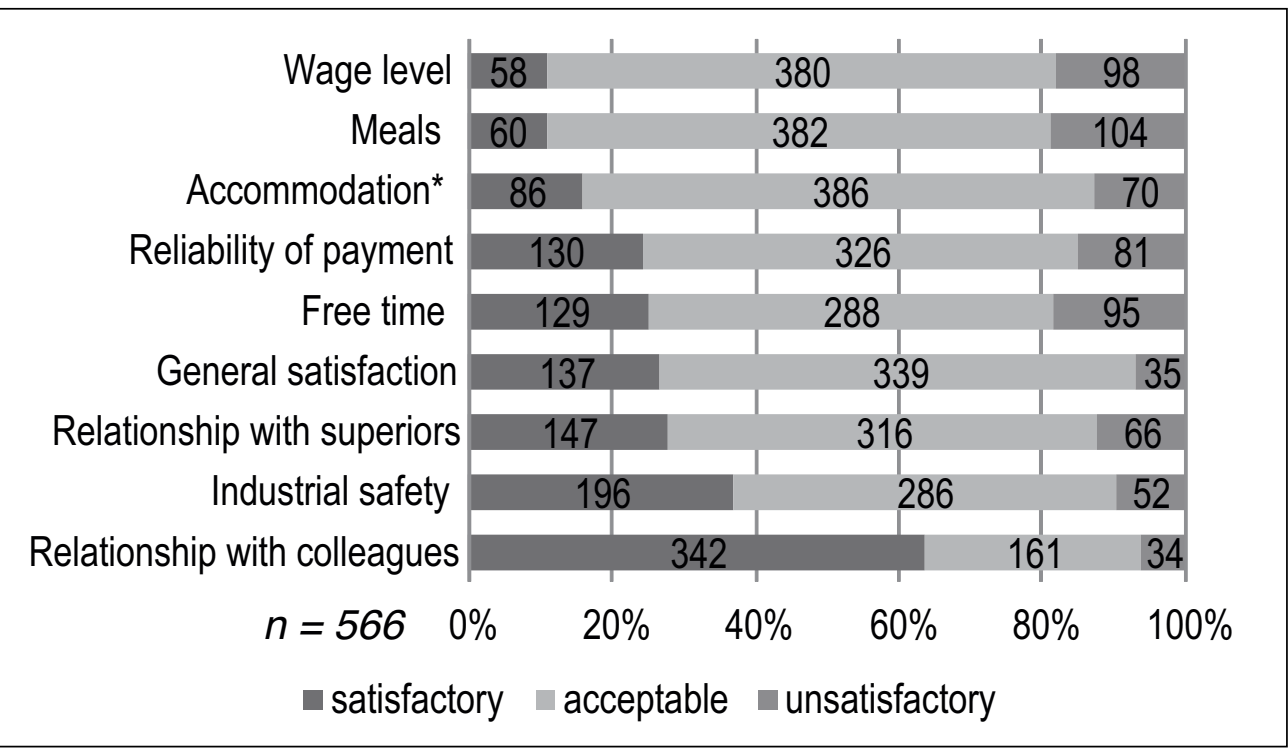

Source: own calculation, employee survey 2008

teristic of the Chinese manufacturing sector is the integration of living and working on the company site. It is disputable, however, to what extent accommodation and meals may truly be seen as social welfare benefits. Here, one must not only consider the above-mentioned function of these services as an instrument of control over the workforce, but also the fact that meals, work clothing and accommodation all quite frequently require payment on the part of workers, as well as goods for daily use, although salaried workers do pay meal costs themselves significantly more frequently $(0.05)$ than industrial workers. Over and above the question of payment, company benefits also partly serve as a system of occupational control over workers, an aspect which is dealt with in detail in studies on the so-called dormitory labour system (cf. LEE 2005, 17; PUN/ SMITH 2007).

The facilities provided at the company site may also be counted among company benefits in the wider sense. An employee of a Japanese company spoke of table tennis tables, karaoke machines, free internet access and television. Courts with basketball hoops are very often to be found, although their use could only be documented in one case; the supposed sport field seemed to be used more for the purposes of assemblies. This leisure programme, as is the case with other free benefits, can be interpreted as an incentive measure, although the former certainly seems to be aimed at the younger, more mobile generation of workers. The company benefits differ between the two data catchment areas in that meals and uniforms are more often free of charge for workers in the peri-urban industrial area than in the inner-city district, the former being significant (0.01). This possibly constitutes an attempt to compensate for the peri-urban location and the lack of alternative accommodation.

Evaluation of workplace quality and priorities of employees: Workplace quality was investigated using nine of the categories found to be relevant in a preliminary study (Fig. 3 ). In the case of wage levels, the absolute proportion of unsatisfied workers is the highest, and is also proportionally greater than that of satisfied workers $(18 \%$ to $11 \%)$. When one takes into account the wage fluctuations presented earlier, this is hardly surprising. Furthermore, the quality of meals was the second most common question to be answered with 'unsatisfied' (19\% unsatisfied to $11 \%$ satisfied). Considering the fact that many employees receive their 
Fig. 4: Subjective priorities for selected aspects of the workplace

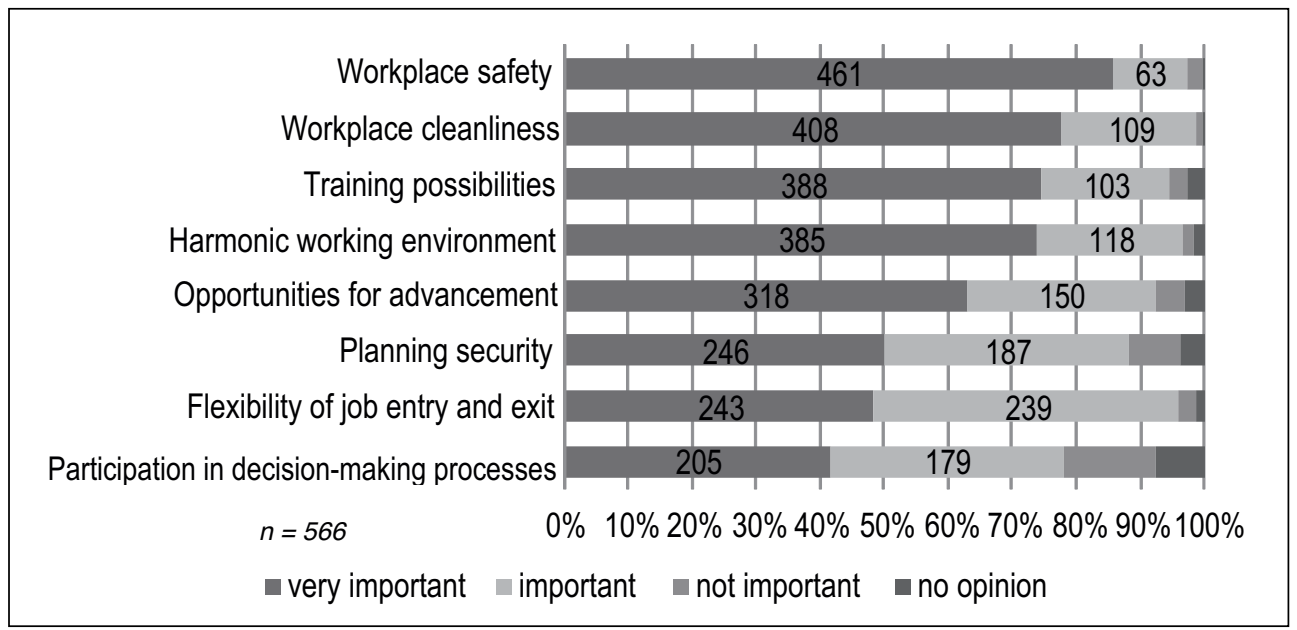

Source: own calculation, employee survey 2008

entire nutrition from the company canteen, it indeed seems plausible that low quality of meals could be a further important determinant for labour turnover, particularly in the case of physically exhausting work. This theory, however, would have to be qualified using a weighting of various problem areas by the employees.

The employees surveyed appeared to be most frequently satisfied with the company climate among colleagues. Safety at the workplace - in contrast to blatantly negative media reports took second place. The relationship to superiors was evaluated slightly more conservatively, but nevertheless very positively. The safety standards at the workplace were either very high, or the survey participants had experienced a comparatively poorer conditions previously.

In the inner-city industrial district, respondents reported significantly more frequently being unsatisfied with wage levels (0.01) and accommodation (0.06) than in the peri-urban district.

In the interpretation of these evaluations, one must take into account which characteristics of the workplace are indeed important (Fig. 4). The previously mentioned security aspect and cleanliness are of immense importance for workers. The third most important aspect is training possibilities, and the fifth is opportuni- ties for advancement, a sign that even - or perhaps especially - the unqualified industrial workers would at least ideally like to realise the ambition of a career. The participation in decision-making processes was most rarely reported to be very important, although a right to participate would possibly be considered to be more important now following the recent increase in public reporting. This all indicates in which areas an adaptable management could act to reduce a labour turnover rate which is clearly too high.

\section{Effects of workplace quality on labour turnover}

Determinants of the turnover rate at the company level

The conceptional preliminary discussion revealed a connection between the flexibility of employment and company success. Positive effects of this flexibility are particularly due to the ability to adapt to fluctuations in the market. Negative effects arise from the loss of knowledge and abilities through frequent job changes. It is thus worthwhile to conduct an analysis of the indicator of this turnover rate and its explanation in a multiple regression model with regard to workplace quality and flexibilisation. Workplace quality and flexibilisation are operationalised using the indicators 
Tab. 4: Descriptive statistics for the variables of the regression model

\begin{tabular}{|c|c|c|c|c|c|c|}
\hline & $n$ & Min & $\operatorname{Max}$ & Mean & $\begin{array}{l}\text { Standard } \\
\text { deviation }\end{array}$ & Explanation \\
\hline \multicolumn{7}{|l|}{ Dependent variable } \\
\hline Turnover rate & 200 & 0 & 100 & 36.08 & 31.74 & $\begin{array}{l}\text { Employees leaving the company as a } \\
\text { percentage of the total number of } \\
\text { employees }\end{array}$ \\
\hline ln (Turnover rate) & 200 & 0 & 4,61 & 3.06 & 1.20 & Natural logarithm of the turnover rate \\
\hline \multicolumn{7}{|l|}{$\begin{array}{l}\text { Workforce-related } \\
\text { variables }\end{array}$} \\
\hline Monthly wage & 216 & 600 & 3,000 & 1,270 & 423.39 & in Yuan \\
\hline $\begin{array}{l}\text { Number of social } \\
\text { welfare benefits }\end{array}$ & 222 & 1 & 5 & 3.71 & 1.12 & Number \\
\hline $\begin{array}{l}\text { Training for new } \\
\text { employees }\end{array}$ & 222 & 1 & 5 & 4.05 & 1.05 & $\begin{array}{l}\text { Intensity of formal and informal } \\
\text { education }\end{array}$ \\
\hline Further education & 222 & 0 & 5 & 2.53 & 1.43 & $\begin{array}{l}\text { Intensity of internal and external } \\
\text { further education }\end{array}$ \\
\hline Problems with employees & 221 & 1 & 5 & 2.86 & 0.94 & Average frequency of six problems \\
\hline $\begin{array}{l}\text { Employees with tertiary } \\
\text { education }\end{array}$ & 212 & 0 & 100 & 32.26 & 30.65 & $\begin{array}{l}\text { as a percentage of the total number of } \\
\text { employees }\end{array}$ \\
\hline $\begin{array}{l}\text { Flexibility-related variables } \\
10 \% \text { increase in the }\end{array}$ & & & & & & \\
\hline $\begin{array}{l}\text { number of employees } \\
\text { Fluctuation of the } \\
\text { number of employees }\end{array}$ & 195 & 0 & 100 & 42.96 & 27.33 & $\begin{array}{l}\text { Spread of the number of employees } \\
\text { as a percentage of the average } \\
\text { number of employees }\end{array}$ \\
\hline $\begin{array}{l}\text { Turnover percentage of } \\
\text { industrial countries }\end{array}$ & 211 & 0 & 100 & 27.76 & 37.93 & as a percentage of total turnover \\
\hline Number of employees & 213 & 1 & 3 & 1.91 & 0.78 & $\begin{array}{l}\text { 1:-1-99, 2: 100-499, 3: } 500 \text { and } \\
\text { above }\end{array}$ \\
\hline
\end{tabular}

Source: own calculation, company survey 2008

introduced above. An overview of the variables of the model can be found in Tab. 4 .

For several dimensions, average values were created from various component indicators: In the group of independent variables, one can thus find the number of social welfare benefits offered, an education index for formal education (double weighting) and training of new employees (simple weighting), a further education index for internal (simple) and external (double) further education programmes offered and a problem index (average value) of the frequency of the six problems with workers.

In addition to the indicators of flexibilisation already mentioned, the importance of industrial countries as a key market (as a percentage of total sales turnover) and the number of employees are included in the model. The natural logarithm of the labour turnover rate is used as a dependent variable, since exponential rather than linear relationships were found between many variables during the data exploration. An investigation of the correlation coefficients between the independent variables showed that these are generally uncorrelated with each other. Only two coefficients are above 0.3 . The highest coefficient of 0.352 is attained by the training and further education indices.

For the explanation of the turnover rate, three multiple regression models were calculated in which a differentiation was made between labour resource-related and flexibility-related variables. The intention here is to pursue the 
Tab. 5: Determinants of the labour turnover rate using a multiple regression model

\begin{tabular}{|c|c|c|c|c|c|c|}
\hline \multirow[t]{2}{*}{ Independent variables } & \multicolumn{2}{|c|}{ All variables } & \multicolumn{2}{|c|}{$\begin{array}{l}\text { Workforce-related } \\
\text { variables }\end{array}$} & \multicolumn{2}{|c|}{$\begin{array}{l}\text { Flexibility-related } \\
\text { variables }\end{array}$} \\
\hline & $\begin{array}{l}\text { stand. } \\
\text { beta }\end{array}$ & sign. & $\begin{array}{l}\text { stand } \\
\text { beta }\end{array}$ & sign. & $\begin{array}{l}\text { stand } \\
\text { beta }\end{array}$ & sign. \\
\hline Monthly wage & -0.135 & $0.073^{*}$ & -0.136 & $0.060^{*}$ & & \\
\hline $\begin{array}{l}\text { Number of social welfare } \\
\text { benefits }\end{array}$ & 0.112 & 0.121 & 0.106 & 0.128 & & \\
\hline Training for new employees & 0.148 & $0.049 * *$ & 0.150 & $0.042 * *$ & & \\
\hline Further education & -0.030 & 0.699 & -0.033 & 0.648 & & \\
\hline Problems with workers & 0.175 & $0.015 * * *$ & 0.197 & $0.004 * * *$ & & \\
\hline $\begin{array}{l}\text { Employees with tertiary } \\
\text { education }\end{array}$ & -0.226 & $0.005 * * *$ & -0.238 & $0.001 * * *$ & & \\
\hline $\begin{array}{l}10 \% \text { increase in the } \\
\text { number of employees }\end{array}$ & 0.114 & 0.107 & & & 0.188 & $0.010^{* *}$ \\
\hline $\begin{array}{l}\text { Fluctuation of the number } \\
\text { of employees }\end{array}$ & 0.158 & $0.029 * *$ & & & 0.158 & $0.036^{* *}$ \\
\hline $\begin{array}{l}\text { Turnover share of industrial } \\
\text { countries }\end{array}$ & 0.234 & $0.001 * * *$ & & & 0.269 & $0.000 * * *$ \\
\hline $\begin{array}{l}\text { Number of employees } \\
\text { (constant) }\end{array}$ & -0.116 & $\begin{array}{l}0.140 \\
0.000^{* * *}\end{array}$ & & $0.000 * * *$ & -0.014 & $\begin{array}{l}0.858 \\
0.000 * * * \\
\end{array}$ \\
\hline Dependent variable & $\ln ($ Turr & er rate) & $\ln ($ Turn & er rate) & $\ln$ (Turn & er rate) \\
\hline $\mathrm{R}^{2}$ & 0.300 & & 0.179 & & 0.138 & \\
\hline corrected $\mathrm{R}^{2}$ & 0.254 & & 0.152 & & 0.118 & \\
\hline F-Test (sign.) & 0.000 & & 0.000 & & 0.000 & \\
\hline Number of observations & 164 & & 192 & & 171 & \\
\hline
\end{tabular}

Significance levels: $* * * \mathrm{p}<1 \%, * * \mathrm{p}<5 \%,{ }^{*} \mathrm{p}<10 \%$

Source: own calculation, company survey 2008

question arising from the conceptual section of whether labour turnover is caused more by a surplus of demand for workers and job change stemming from this, or whether it is more a result of flexible production methods and the short-term employment relationships connected to this. The summarised results of the regression analysis (Tab. 5) show that the labour resource-related variables possess a slightly higher explanation power than those related to flexibility. Altogether, however, the results point to the fact that both factors exert an influence on labour turnover, as indeed was expected. The explanation power of the complete model is, at $25.4 \%$, acceptable for survey data.
The following individual results are particularly noteworthy against the background of the current situation in the Pearl River Delta. Among the labour resource-related variables, a higher average monthly wage reduces labour turnover, as is to be expected. More surprising is the fact that employees with a tertiary education (university or polytechnic) change jobs less frequently than poorly qualified workers. Generally, one could have assumed that more highly qualified workers have a wider range of employment options. But because of the general shortage of workers, it seems to be actually poorly qualified workers in the Pearl River Delta who react to minimal differences in wages by changing jobs. 
The most interesting results are those for training and further education as well as social welfare benefits. The more comprehensive a training or education programme offered to new employees is, the higher the labour turnover rate. Workers obviously exploit the additional qualification gained to receive higher wages at other companies. Further education does not reduce fluctuation either, indeed having no significant influence. Social welfare benefits also prove not to be a substitute for higher wages. Their influence on labour turnover is positive, but not significant. This result rather confirms that the total provision of services for employees based on the notion of control is indeed becoming less attractive for the younger generation of migrant workers.

Among the flexibility-related variables, the marketing orientation of companies towards industrial countries possesses the greatest explanation power. The standardised beta coefficient is also higher than that of every individual workforce-related variable. The integration into global value chains thus seems to demand a particularly high degree of short-notice adaptation ability from electronics firms in the Pearl River Delta, which have a direct effect on labour turnover. Companies whose employee numbers fluctuate more strongly during the year because of seasonal influences naturally have a higher rate of labour turnover. Despite the significant differences in the turnover rate between Chinese and foreign firms (Tab. 2), these differences disappear in the regression model when other independent variables are used (Tab. 5). An additional model calculated with an owner dummy did not lead to an improvement of the explanation power or to a significant influence of the dummy.

In summary, the results of the regression analysis lead to the conclusion that wage levels are the principal tool for companies when it comes to establishing a stable stock of workers. Social welfare benefits designed to exercise control over workers and qualification initiatives, on the other hand, lead to a higher rate of labour turnover, and are thus not worthwhile for the company that carries the costs for these measures. Since companies with more highly qualified workers are less vulnerable to high labour turnover rates, a freeloader pattern of behaviour, in which other companies or the state fund the qualification of workers, is probably the most successful strategy in the short term.
In the case of one-sided orientation towards global markets, which have proven to be particularly susceptible to strong fluctuations in demand, a diversification into the Asian or local market seems to have a balancing effect. These preliminary explanation attempts will be elaborated upon in the continued course of the research project along with findings on the connection between jobs and job changes from the employee perspective.

\section{Workplace-related job change and mobile workers}

Job change and worker characteristics: The duration of employment and the number of previous jobs held are indicators for the mobility or 'readiness to change' of workers. $17 \%$ of those sampled reported an employment period of up to two months. This figure must be viewed in connection with the date of the survey (22/23 March), which is shortly after the spring festival (7-10 February), since the spring festival is a time which often sees significant job changes. Altogether, $51 \%$ of the workers had been working for the same company for a maximum of six months, while only $8 \%$ had been doing so for more than three years. It is noticeable that the average duration of employment was longer in the inner-city district than in the peri-urban district (18.9 vs. 11.2 months) - a discrepancy which is intensified by the higher average age.

At first glance, the number of jobs has a positive connection with age, as was expected (Tab. 6). Among the relatively young workforce - only $17 \%$ are older than 29 years - the number of previous jobs held varies in a nonlinear fashion between the age groups: the 1924 age group reported more frequently a larger number of previous jobs than the 25-29 age group. Although the average age in the innercity district is significantly higher, the workers there reported that they had a similar number of previous jobs (1.5 in the inner-city district vs. 1.6 in the peri-urban district). The mobility of the younger workers is thus generally greater. The group of more highly qualified workers was also found to have a larger number of previous jobs than those with a lower education level (Tab. 6), although one must take into account the fact that education reforms have led to a generally higher standard of education for younger workers, and that the shortage of workers has only been beneficial for worker mobility since 2004 . 
Tab. 6: Number of previous jobs, differentiated according to age and education level

\begin{tabular}{lccccc} 
& \multicolumn{2}{c}{ Previous jobs (\%) } & & & absolute \\
& 0 & 1 & 2 & 3 & numbers \\
\hline Age & 71 & 17 & 11 & 1 & 76 \\
up to 18 & 66 & 20 & 11 & 3 & 284 \\
$19-24$ & 51 & 30 & 13 & 5 & 76 \\
$25-29$ & 68 & 20 & 7 & 5 & 93 \\
30 and older & 65 & 21 & 10 & 4 & 529 \\
Total & & & & & \\
Education leve ${ }^{*}$ & 68 & 19 & 10 & 3 & 300 \\
$\begin{array}{l}\text { Maximum of an intermediate school } \\
\text { qualification }\end{array}$ & & & & & \\
$\begin{array}{l}\text { Minimum of a secondary school } \\
\text { qualification }\end{array}$ & 61 & 23 & 11 & 5 & 235 \\
Total & 65 & 20 & 10 & 4 & 535 \\
\hline
\end{tabular}

*The differences between the two groups are weakly significant on the basis of the $\mathrm{Chi}^{2}$-Test (6\% margin of error). Source: own calculation, employee survey 2008

With these results, however, one must take into account the job market-related conditions in the Pearl River Delta. An increased shortage of workers has emerged there since 2004. This has led to a situation in which younger workers have a wider range of jobs to choose from, which is a very desirable development from the point of view of employees. From the perspective of the companies affected, a high turnover rate must be considered problematic, particularly in the case of more highly qualified workers, since it creates a tendency for more knowledge to be lost and, in some cases, for greater financial investment in further education which eventually proves to be useless for the employer.

Reasons for changing jobs: The company survey suggests a connection between labour turnover and wages as well as education level; secondary data also indicate a surplus of vacant jobs. In addition, the employee survey provides reasons for changing jobs on the part of the workers themselves (Tab. 7). These are related to workplace quality and flexible company organisation, but are also partly linked to the residency status of the workers.

The most common reason for employees to change jobs was found to be fluctuation of effective monthly wages. The second most common reason was poor hygiene at the workplace $(23 \%)$, with the third being a return to one's home region for the period of the Chinese New Year festival $(18 \%)$. This is not surprising for a number of reasons, but particularly because the number of vacation days was not contractually regulated in the private sector until the introduction of the employment contracts law. Each worker was entitled to only three days during the period of the New Year festival, which, in most cases, was not even enough to cover the travel time to the workers' home regions. Most employees thus consider their employment relationship to be terminated automatically once the number of vacation days is exceeded. The official end of a contract or the acquisition of another job through friends or relatives were named less frequently as reasons for a change of jobs ( $7 \%$ and $8 \%$ respectively).

The answer frequencies differ between the two investigation areas only in the point 'ending of the contract', which was named much more frequently in the inner-city district as a reason for changing jobs than in the peri-urban district (10 vs. 43 mentions). More highly qualified workers responded similarly to poorly qualified workers. As expected, employees in a salaried position most rarely named workplace hygiene $(16 \%)$ as the reason for their last job change. More interesting is the distinction between men, who much more frequently cited low wages and workplace hygiene (151 and 90 mentions respectively), and women (128 and 78 mentions). Women, however, much more frequently cited the journey home for the spring festival as a reason for the change in jobs (86 vs. 41 mentions). Of all the age- 
Tab. 7: Reasons for changing one's previous job

\begin{tabular}{lccc} 
Job change due to ... (multiple answers) & Frequency & Percentage & Percentage of cases \\
\hline low wages & 280 & 39 & 54 \\
poor workplace hygiene (noise, smell, & 170 & 23 & 33 \\
light, temperature) & & & \\
end of the employment relationship because of trip & & & \\
home for the spring festival & 127 & 18 & 25 \\
acquisition of a new job through friends or relatives & 56 & 8 & 11 \\
end of the contract & 53 & 7 & 10 \\
other reasons & 40 & 5 & 8 \\
Total number of answers & 726 & 100 & 141 \\
\hline
\end{tabular}

Source: own calculation, employee survey 2008

groups surveyed, furthermore, those over the age of 30 most frequently gave low wages as a reason $(45 \%)$. This group is obviously the least ready to accept wage disadvantages; its members probably more frequently have to support a family with their income than younger, single workers.

\section{Conclusion and policy recommendations}

The presentation and contrasting of the empirical results prove that the electronics industry in the Pearl River Delta is indeed characterised by a high degree of labour turnover: It could be confirmed, firstly, that flexibility in the sense described by ATKINSON (1984) is a means of organising companies, which is particularly made use of by companies embedded in global value chains. Secondly, workplace-related characteristics of labour turnover, employee characteristics and personal reasons for job change were found to be important determinants. Altogether, the two influencing factors were found to be of similar importance.

In the area of workplace quality, wage levels were found to be the central criterion for changing jobs. Due to low wages, which are, on average, well above the legal minimum wage, but subject to very severe fluctuations, workers in the lower-income sector react to even a small difference in wages by changing employers. The shortage of workers, which is identified as a central problem by companies, intensifies this situation. Company benefits do not offer any significant incentive to remain at a firm for longer periods of time either - here, accommodation and meals are most commonly provided, although meals in particular are very frequently deemed to be insufficient by employees.

The qualification initiatives offered at the workplace in the form of training and further education, which are of importance with regard to labour turnover and for technological upgrading processes of companies, possibly also contribute to a further increase of labour turnover at the company level. Education level and low age increase the probability of job change at the individual level. This connection seems to be due mostly to the high degree of sensitivity of workers to wage differences and the size of the labour market coupled with the simultaneous shortage of workers. Since it is not worthwhile in such a situation for an individual company to provide qualification measures, an explanation must also be found here for the low frequency with which training and further education programmes are offered. The empirical investigation provided evidence to suggest that in the electronics industry of the Pearl River Delta, a qualification lock-in indeed exists in the area of labour-intensive and wage-sensitive production. Frequent job changes and few possibilities for further qualification strengthen each other reciprocally, since workers change employers both in seeking higher wages and because of the opportunity achieve this more effectively following the attaining of a qualification.

In summary, three bundles of causes, all connected with one another, could be found for worker shortage and a high rate of labour turnover: 
- company influences, shaped by a company organisation system aiming for numerical and financial flexibility and reacting to the necessities of being embedded in global value chains;

- assessment of the workplace quality determined by individual characteristics of the workers (lower age groups, education level, gender) and their subjective priorities and evaluations (stage of life, promotion orientation, family support payments), and

- regional influences shaped by the dynamic, globalised development of the Pearl River Delta and its socio-demographic transformation (internal migration led by migrant workers), which were not explicit subjects of this investigation, but are nevertheless important for the interpretation of the results.

One of the decisive questions for the maintenance of competitiveness in the region through upgrading processes is that of how the high labour turnover rate can be generally reduced and more smoothly organised for both companies and workers, and how the significance and value of qualification can be increased at the same time. Several state-subsidised flagship companies have, without doubt, already been successful in producing considerable technological innovation (KROLL/SCHILLER 2010), without the large number of small and medium-sized companies being able to keep up with this development. One possibility to change this lies in the strengthened use of intermediates on the job market, which are beginning to appear in the form of a private sector-organised employment agency and temporary labour agency branch (XUE et al. 2010). During the preliminary selection of potential employees, the organisation of security collateral and the provision of social welfare benefits, these agencies could make a mediation contribution and could also take on responsibilities in the area of qualification. Over and above this, a progressing regulation of work at all education levels would be profitable for both the employee as well as the employer side of the equation by increasing the continuity of employment relationships. This, however, would be a development which would tend to move away from the concept of a flexible firm, and which may not be possible for firms to implement due to the rapid adaptation required within the global value chain. Flexibility and upgrading, howev- er, are connected in an interdependent relationship. Only a strategic reorientation of companies towards long-term-focused business models will be able to lead to appropriately large investment being made in education and employee binding, with numerical flexibility no longer being used as the only option for adapting to global market fluctuations.

In the case of education and qualification, due to its character as a public resource, state institutions are also obliged to a certain degree to provide or support appropriate programmes. Here, at the district level, this would be a starting point for cooperation between companies and education institutions in the form of regional qualification alliances. As part of a research project currently in progress, for example, a cooperation between ThyssenKrupp in Zhongshan and a local public further education institution is being investigated (interview 10.4 2010). Here, basic questions pertaining to the organisation of the Chinese education system are addressed which go beyond the scope of this paper. The attractiveness of the working and living environment ("soft location factors") are also increasingly moving into the focus of the second generation of migrant workers, and particularly of more highly qualified workers.

The empirical results of the research project form an image of the specific situation of the electronics industry in the Pearl River Delta at the time of the survey. Further research is necessary in several areas, especially concerning the importance and organisation of internal and external company further education, in the course of which the perspective of companies should be connected with that of employees. From the point of view of companies, a more exact investigation of the effects of labour turnover and qualification on upgrading processes and company success would be interesting. From the point of view of employees, a focus on more highly qualified workers in the core workforce would provide a valuable knowledge supplement. In addition, external providers of training and further education should be included as a target group in an investigation.

\section{Acknowledgement}

The authors would like to thank two anonymous reviewers for their helpful comments on an earlier version of this paper and Kerry Jago for the translation of the 
original manuscript. The empirical research used in this paper was carried out within the Priority Programme (SPP) 1233 "Megacities - Megachallenge: The Informal Dynamics of Global Change" funded by the German Research Foundation (DFG), whose support is thankfully acknowledged.

\section{References}

Albrecht, S. (2002). Regionale Arbeitsmärkte und Flexibilisierungsprozesse. Geographische Zeitschrift, (90)3-4, 180-193.

Albrecht, S. (2005). Flexibilisierung der Arbeit: Prozesse und Strategien aus geographischer Sicht. Koblenz. (Koblenzer Geographisches Kolloquium, 27).

AtKinson, J. (1984): Manpower strategies for flexible organizations. In: Personnel management, 16, 28-31.

BRANDT, O. (2009): Lokalisiertes Lernen oder funktionale Spezialisierung - wie nachhaltig gelingt die Integration von gering Qualifizierten in den regionalen Arbeitsmarkt? Antworten aus Niedersachsen. Hannover. (Diss.)

Chan, K.W. (2010a): A China paradox. Migrant labor shortage amidst rural labor supply abundance. In: Eurasian Geography and Economics, (51)4, 513-531.

CHAN, K.W. (2010b): The global financial crisis and migrant workers in China. 'There is no future as a labourer; returning to the village has no meaning'. In: International Journal of Urban and Regional Research, (34)3, 659-678.

CLB (China Labour Watch)(2008): Minimum monthly wage standards in selected provinces/ municipalities/cities in China. Internet: http://www. chinalaborwatch.org/2006 Editorials/07-24-2006 Minimum Wage Chart.htm, 18.10. 2010.

CoHen, W.M./Levinthal, D. (1990): Absorptive capacity: a new perspective on learning and innovation. In: Administrative Science Quarterly. 35, 128-152.

Enright, M./ScotT, E./Chang, K. (2005): Regional powerhouse. The Greater Pearl River Delta and the rise of China. Singapore.

ERnst, D./NAUGHTON, B. (2008): China's emerging industrial economy. Insights from the IT industry. In: McNally, C. (Ed.): China's emergent political economy. Capitalism in the dragon's lair. Abingdon, 39-59.

FAN, C. C. (2008): China on the move. Migration, the state, and the household. London. (Reprint: Routledge studies in human geography, 21).

GDSTATS (Statistics Bureau of Guangdong Province) (2010): Guangzhou statistical yearbook 2010. Internet: http://www.gdstats. gov.cn/tjnj/ml_e.htm, 20.2. 2011.

GeFFKen, R./MA, D./Hsie, S.-M. (2010): Das chinesische Arbeitsvertragsgesetz. Hamburg.

Gerlach, K./Meyer, W./Tsertsvadze, G. (2002): Entwicklung der qualifikatorischen Segregation im Verarbeitenden Gewerbe. In: Bellmann, L./Kölling, A. (Hrsg.): Betrieblicher Wandel und Fachkräftebedarf. Nürnberg, 51-84.

German Federal Employment Agency (Bundesagentur für Arbeit) (2010): Arbeitsmarkt 2009. Nürnberg. (Amtliche Nachrichten der Bundesagentur für Arbeit 58,2).
HE, G. (2006): The shortage of peasant workers in the Pearl River Delta Region. An Explanation based on Todaro migration model. In: Asian Social Science, (2)12, 41-52.

HeBel, J./Schucher, G. (2006): Flexibility and security in China's emerging 'Socialist' market labour regime. In: Baur, M. / Gransow, B. / Jin, Y. / Shi, G. (Eds.): Labour mobility in urban China. An integrated labour market in the making? Berlin, 19-49. (Berliner China-Studien, 46)

HKTDC (Hong Kong Trade Development Council)(2010): Mounting price pressure on China exports. Research Report. Hong Kong.

Hürtgen, S./ Lüthje, B./Schumm, W./Sproll, M. (2009): Von Silicon Valley nach Shenzhen. Globale Produktion und Arbeit in der IT-Industrie. Hamburg.

JiAnG, B./BAKER, R./FraZIER, G.V. (2009): An analysis of job dissatisfaction and turnover to reduce global supply chain risk. Evidence from China. In: Journal of Operations Management, 27, 169-184.

Kilian, P./Beisswenger, S./Xue, D. (2010): Floating or settling down? Migrant workers and mega-urban development in the Pearl River Delta, China. In: Geographische Rundschau - International Edition, (6)2, 50-56.

KIM, L. (1997): Imitation to Innovation. Dynamics of Korea's technological learning. Boston, MA.

KNIGHT, J.B./DEnG, Q./Li, S. (2011). The puzzle of migrant labour shortage and rural labour surplus in China. In: China Economic Review (forthcoming).

Kroll, H./Schiller, D. (2010): Establishing an interface between public sector applied research and the Chinese enterprise sector: Preparing for 2020. In: Technovation, (30)2, 117-129.

LEE, C.K. (2005): Livelihood struggles and market reform. (Un)making Chinese labour after state socialism. Geneva. (ILO Occasional Paper).

LEWIS, W.A. (1954): Economic development with unlimited supplies of labour. In: The Manchester School, (22)2, 139-191.

LÜthJE, B. (2008): Arbeitspolitik in der chinesischen IT-Industrie. Neue Perspektiven in der Diskussion um internationale Arbeitsstandards. Frankfurt am Main. (Institut für Sozialforschung: Studie im Auftrag der Hans-Böckler-Stiftung).

Meyer, S./Schiller, D./Revilla Diez, J. (2009): The Janus-faced economy. Hong Kong firms as intermediaries between global customers and local producers in the electronics Industry. In: Tijdschrift voor Economische en Sociale Geografie, (100)2, 224-235.

Meyer, S./Schiller, D./Revilla Diez, J. (2012): The localization of electronics manufacturing in the Greater Pearl River Delta, China. Do global implants put down local roots? In: Applied Geography, 32, 119-129.

Pun, N. (2005): Made in China. Subject, power and resistance among women workers in a global workplace. Durham.

Pun, N./Smith, C.J. (2007): Putting transnational labour process in its place. The dormitory labour regime in post-socialist China. In: Work Employment Society, (21)1, 27-45. 
Pun, N./ Lu, H. (2010): Unfinished proletarianization. Self, anger, and class action among the second generation of peasant-workers in present-day China. In: Modern China, (36)5, 493-519.

ReILLY, P.A. (1998): Balancing flexibility. Meeting the interests of employer and employee. In: European Journal of Work and organizational Psychology, (7)1, 7-22.

Staiger, B. (Hrsg.)(2008): Das große China-Lexikon. Geschichte, Geographie, Gesellschaft, Politik, Wirtschaft, Bildung, Wissenschaft, Kultur. Darmstadt.

SCHILLER, D. (2011): The role of foreign and domestic firms in regional innovation systems of latecomer countries. Empirical evidence from the electronics industry in the Pearl River Delta. Erdkunde, (65)1, 25-42.

SHEN, J. (2007): Labour disputes and their resolution in China. Oxford.

SMith, T. (Hg.) (2006): Challenging the chip. Labor rights and environmental justice in the global electronics industry. Philadelphia.

StURGEON, T. (2002): Modular production networks. A new American model of industrial organization. In: Industrial and Corporate Change, (11)3, 451-496.

The Economist (2010): The next China. As the supply of migrant labour dwindles, the workshop of the world is embarking on a migration of its own. In: The Economist, 29.7. 2010. Internet: http://www.economist.com/ node/16693397, 12.9. 2010).

TSERTSVADZE, G. (2005): Qualifikatorische Segregation. Entwicklung und Bestimmungsgründe. Eine theoretische und empirische Analyse. Aachen.
VAlverde, M./TREgaKIS, O. (2000): Labor flexibility and firm performance. In: International Advances in Economic Research, (6)4, 649-661.

WANG, M.Y./WU, J. (2010): Migrant workers in the urban labour market of Shenzhen, China. In: Environment and Planning A 42. (forthcoming).

Whiteley, A./Cheung, S./Quan, Z.S. (2000): Human resource strategies in China. Singapore.

XuE, D./Lin, T./KraAs, F./Kilian, P. (2010): Informal job-seeking agencies and their role in the 'World Factory' of the Pearl River Delta. A case study in Tangxia Township, Dongguan City, Guangdong Province. In: Geographical Research, (29)10, 1793-1801. (Chinese with an English summary).

YANG, D.L. (2005): China's looming labor shortage. In: Far Eastern Economic Review, (168)2, 19-24.

Yue, Z./Li, S./Feldman, M.W./Du, H. (2010). Floating choices. A generational perspective on intentions of rural urban migrants in China. In: Environment and Planning, A 42, 545-562.

Yu, H./HuAng, Y. (2009): Impact of the global economic crisis on the Pearl River Delta and the Yangtze River Delta. Singapore. (East Asian Institute Background Brief No. 477, National University of Singapore).

Yu, H./ZHANG, Y. (2009): New initiatives for industrial upgrading in the Pearl River Delta. Singapore. (East Asian Institute Background Brief No. 464, National University of Singapore). 